\title{
JOURNAL.RU
}

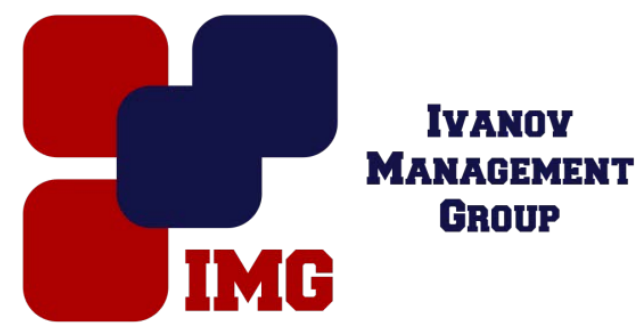

Белоус Д.С., Мельников И.Н., Пичхидзе С.Я., Кайргалиев Д.В., Ермошин А.Г . ФГБОУ ВО «Саратовский государственный технический университет им. Гагарина Ю.А.»

Саратов, Россия

doi: 10.18411/lj-30-11-2016-4-02

idsp 000001:lj-30-11-2016-4-02

\section{Кислоты в огнетушащих составах}

\section{Аннотация}

Рассмотрена коррозия металлов в растворах кислот.

Ключевые слова: щавелевая кислота, коррозия.

Большинство пожарных автомобилей оснащены цистернами из углеродистой стали. Продолжительность их службы зависит от вида кислот в огнетушащем составе и величины его рН. Определенный интерес представляет собой щавелевая кислота, которая входит в составы для удаления ржавчины и оксидных пленок на металле. Проведенные исследования показали, что даже незначительное содержание щавелевой кислоты в огнетушащем растворе приводит к коррозии металлических емкостей (цистерн) пожарных автомобилей.

К аналогичным результатам приводит наличие и других органических кислот в огнетушащих составах.

\section{Литература}

1. Мельников И.Н., Попова Э.А., Ермошин А.Г. Применение этиленгликолевых антифризов в тушении пожаров. В сборнике: КОМПЛЕКСНЫЕ ПРОБЛЕМЫ ТЕХНОСФЕРНОЙ БЕЗОПАСНОСТИ Материалы Международной научно-практической конференции. 2016. С. 258-260.

2. Хаврошина Ю.О., Белоус Д.С. Разработка огнестойких составов для пропитки огнезащитных костюмов пожарных и спасателей. http://www.school-science.ru/2017/19/26192

3. Никонович С.Л., Мельников И.Н., Кайргалиев Д.В. К созданию огнетушащих составов, применимых в условиях суровой зимы. В сборнике: Современные тенденции развития правовой науки Международная научно-практическая конференция. 2016. С. 198-201. 